\title{
RADIOPACITY OF CALCIUM HYDROXIDE CEMENT COMPARED WITH HUMAN TOOTH STRUCTURE
}

\author{
RADIOPACIDADE DO CIMENTO DE HIDRÓXIDO DE CÁLCIO COMPARADA \\ A DAS ESTRUTURAS DENTAIS HUMANAS
}

Karina Lopes DEVITO ${ }^{1}$, Ana Isabel ORTEGA², Francisco HAITER-NETO ${ }^{3}$

1- PhD Student, Department of Oral Radiology, Piracicaba Dental School, University of Campinas, Brazil.

2- MSc, Department of Oral Radiology, Piracicaba Dental School, University of Campinas, Brazil.

3- Associate Professor, Department of Oral Radiology, Piracicaba Dental School, University of Campinas, Brazil.

Corresponding address: Karina Lopes Devito - Faculdade de Odontologia de Piracicaba - UNICAMP - Departamento de Radiologia Avenida Limeira, 901 - CP 52 - CEP: 13414-903 - Piracicaba - SP - Brazil - Email: radiologia@fop.unicamp.br - Phone: 55-19-3412-5327

Received: January 06, 2004 - Returned for modification: March 03, 2004 - Accepted: March 22, 2004

\begin{abstract}
A

ims. All materials added to teeth should present an adequate radiopacity to allow the detection of secondary caries. Usually, in extensive cavities, base materials like calcium hydroxide cement are used for the purpose of protecting the pulp. In an attempt to improve the efficiency of radiographic detection of this material, this study aimed to determine the radiopacity of three calcium hydroxide cements and to compare the radiopacity of these materials with dentin and enamel. Methods. Radiographs were taken of 1-mm thick specimens of three calcium hydroxide cements: Hydro-C, Dycal and Life, an aluminium stepwedge, a lead foil, and one 1-mm thick human tooth slice. Densitometric measurements were obtained after radiographic processing. The radiopacity values of the calcium hydroxide cements, dentin and enamel were expressed in terms of the equivalent thickness of aluminium. Results. The analysis of variance indicated statistically significant difference only for Life, which presented the lowest radiopacity when compared to the other cements. However, all cements and enamel possessed a radiopacity equivalent to $2 \mathrm{~mm} \mathrm{Al}$, while dentin presented a radiopacity equivalent to $1 \mathrm{~mm}$ Al. Conclusion. All tested cements presented a similar radiopacity to that of enamel and they meet the ISO 4049 specifications.

Uniterms: Radiopacity; Calcium hydroxide cement; Enamel; Dentin.
\end{abstract}

\section{RESUMO}

$O$

bjetivos. Todos os materiais adicionados aos dentes deveriam apresentar uma adequada radiopacidade para permitir a detecção de cáries secundárias. Geralmente em cavidades extensas, materiais de base, como o cimento de hidróxido de cálcio, são usados com a função de proteger a polpa. Na tentativa de melhorar a eficiência na detecção radiográfica deste material, este estudo foi realizado com o objetivo de determinar a radiopacidade de três cimentos de hidróxido de cálcio e comparar a radiopacidade destes materiais com a da dentina e do esmalte. Materiais e Método. Foram radiografados corpos de prova de $1 \mathrm{~mm}$ de espessura de três cimentos de hidróxido de cálcio: Hydro-C, Dycal e Life, uma escala de densidade de alumínio, uma lâmina de chumbo e um corte de dente humano de $1 \mathrm{~mm}$ de espessura. As densidades ópticas foram obtidas após o processamento radiográfico. Os valores de radiopacidade dos cimentos de hidróxido de cálcio, dentina e esmalte foram expressos em espessuras equivalentes de alumínio. Resultados. A análise de variância indicou diferença estatisticamente significativa apenas para o cimento Life que apresentou a menor radiopacidade quando comparado aos outros cimentos. Entretanto, todos os cimentos e o esmalte possuíram uma radiopacidade equivalente a $2 \mathrm{~mm}$ de $\mathrm{Al}$, enquanto a dentina apresentava radiopacidade equivalente a $1 \mathrm{~mm}$ de Al. Conclusão. Todos os cimentos testados apresentaram radiopacidades semelhantes à do esmalte, estando de acordo com as especificações da ISO 4049.

Unitermos: Radiopacidade; Cimento de hidróxido de cálcio; Esmalte; Dentina. 


\section{INTRODUCTION}

It is important that all materials added to teeth like base, lining or restorative materials present an adequate radiopacity to allow detection of secondary caries and excess material at the proximal surfaces, evaluation of proximal contour, differentiation between base materials, restorative materials and surrounding dental structures, detection of voids in the restorations and location of some material that has been accidentally aspired, inhaled or can eventually be in soft tissues ${ }^{1-3,5-8,20,21}$.

Usually, in extensive cavities, base materials are used beneath the restorative material, with the purpose of helping in the reparative process of the affected pulp and to protect it against the aggressions to which it may be submitted. The base material is used to replace the dentin that was destroyed by caries and/or cavity preparation. A variety of materials has been used as base ${ }^{13}$.

Calcium hydroxide cement is commonly used as base beneath composite restorations because it is considered to be beneficial to the dentin-pulp complex. This cement allows decalcified dentin to be mineralized and induces the formation of sclerosed and repaired dentin, as it has antibacterial properties due to its high $\mathrm{pH}^{12}$.

A large number of studies emphasize the advantageous biological properties of calcium hydroxide cement, but only a very limited number evaluate the radiopacity of this material. Abreu, et al. ${ }^{2}$, in 1977, investigated the radiopacity of 28 dental materials including two commercially available calcium hydroxide cements: Hydrex and Dycal. After densitometric measurements, these materials were included in the group of those presenting moderate radiopacity, meaning that they were not easily detectable in the dental structures. McComb ${ }^{12}$, in 1983, studied five calcium hydroxide cements and the results of the radiopacity tests indicated that four of the commercial materials had similar radiopacities, which were greater than that of human dentin and would show up well on radiographs.

Based on the limited literature and in the attempt to improve the efficiency of radiographic detection of calcium hydroxide cement, this study evaluated the radiopacity of three calcium hydroxide cements and compared it to the radiopacity of dentin and enamel.

\section{MATERIALAND METHODS}

The radiographs were obtained using a dental X-ray machine (General Electric Co., USA) model 1000, 70kVp, $10 \mathrm{~mA}, 0.5 \mathrm{~mm}$ of inherent filtration and $1.5 \mathrm{~mm}$ of aluminium added filtration. The focus-film distance was kept constant with the use of a device that provided an incidence of the radiation beam perpendicular to the film and the radiographed objects. Pilot tests were carried out to determine the exposure time of $0.16 \mathrm{~s}$, which was defined as that presenting an optical density of $1( \pm 0.1)$ in the radiographic image of $10 \mathrm{~mm}$ step.

Occlusal EO-41P films (Eastman Kodak Co., Rochester,
NY, USA) were used. The radiographed objects were samples of three commercially available calcium hydroxide cements: Hydro-C (Dentsply/York Division Co., USA), Dycal (Dentsply/York Division Co., USA) and Life (Kerr, Portland, Oregon, USA); an aluminium stepwedge with thickness varying from 1 to $12 \mathrm{~mm}$, with increments of $1 \mathrm{~mm}$; a lead foil (to determine the base density and fog) and one slice of human molar of 1-mm thickness (mesiodistal direction).

Eight specimens of each tested material were prepared with a thickness of $1 \mathrm{~mm}( \pm 0.1)$, adding up to 24 cement samples. This thickness was used because it most closely resembles that of dental restorations and was established by a caliper (Mitutoyo, Japan). The materials were inserted into 1-mm deep and 4-mm internal diameter elastomer molds for fabrication of the samples. The cements were within the validity period and were prepared according to the manufacturer's instructions.

All specimens of tested calcium hydroxide cement, the aluminium stepwedge, the lead foil and the tooth slices were placed on the same occlusal film, to minimize possible variations with regard to film and radiographic processing (Figure 1). Five repetitions (radiographs) of this set were obtained.

The films were processed using a Gendex GPX (Dentisply/Gendex Division, Des Plaines, IL, USA) processing unit and standard chemicals (Eastman Kodak Co., Rochester, NY, USA) that had not been previously used.

After development, densitometric measurements of the images of each cement specimen, all the steps of the stepwedge, lead foil and enamel and dentin were obtained for all five radiographs, using a digital densitometer (MRA, Ribeirão Preto, SP, Brazil). Three measurements were obtained for each cited area and the means of these readings were calculated.

The radiopacity values of the calcium hydroxide cement, dentin and enamel were expressed in terms of equivalent aluminium thickness (mm Al). Then, the radiopacities of these materials were compared with that of the dental

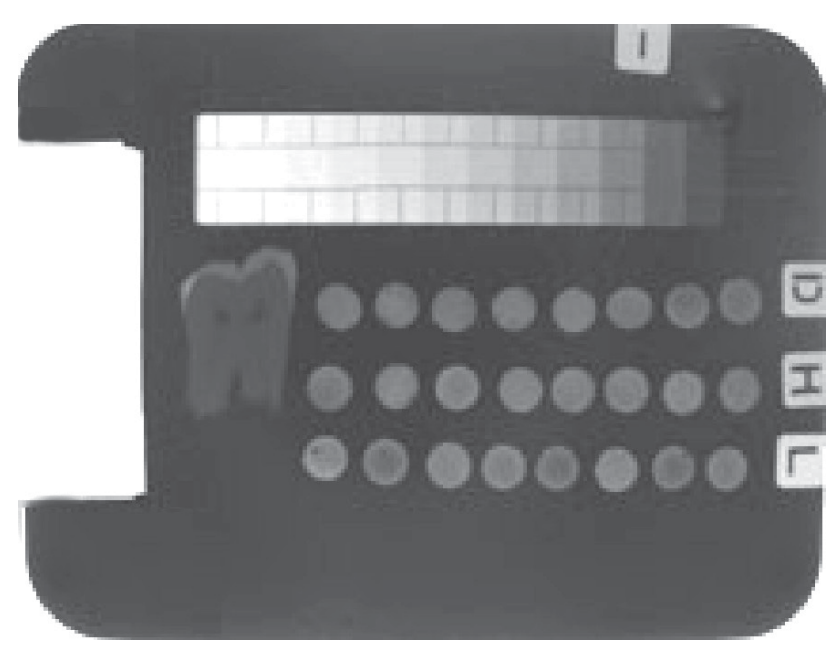

FIGURE 1- Radiographic image of the aluminium stepwedge, lead foil, slice of the molar and specimens of each tested cement 
structures.

Statistical differences between the radiopacity values of the three cements were tested by analysis of variance (ANOVA).

\section{RESULTS}

Analysis of variance showed a statistically significant difference between the means of the tested cement densities $(p=0.0013)$. Each of the cements, as well as the enamel and the dentin were expressed as equivalent aluminium thickness. The optical densities found for the 1-mm aluminium step ranged from 1.47 to 1.58 . The optical densities for the 2-mm step were 1.70 to 1.82 . Means, standard deviations and the equivalent aluminium thickness of the materials are presented in Table 1.

\section{DISCUSSION}

Decisions on what should be the radiopacity of a material added to the tooth has been discussed by several authors. Prévost, et al. ${ }^{14}$, Abou-Tabl, et al. ${ }^{1}$ and Shah, et al. ${ }^{17}$ suggest that the materials should present a radiopacity not less than that of the dentin that is being replaced, so that it is not misinterpreted as decalcified dentin.

Many authors suggest that a radiopacity value higher than that of enamel is desirable in order to detect cements, bases and restorative materials ${ }^{6,8,11,15,18,19}$. Sewerin ${ }^{16}$, Espelid, et al. ${ }^{7}$, Chan, et al. ${ }^{4}$ add that a moderate degree of radiopacity is preferable to a high degree. A very high radiopacity, like that of amalgam, does not provide the best condition for detecting radiolucent areas, such as recurrent caries adjacent to restorations.

According to the International Standards Organization ISO $4049^{10}$ the radiopacity of posterior composite resins must be higher than that of an equal aluminium thickness, if a manufacturer claims that a material is radiopaque. Materials

TABLE 1- Means and standard deviations (s.d.) of optical densities and the equivalent aluminium thickness from each material

\begin{tabular}{llc}
\hline Material & Mean (s.d.) & $\begin{array}{c}\text { Equivalent aluminium } \\
\text { thickness }\end{array}$ \\
\hline Life & $1.57(0.03)^{\mathrm{a}}$ & $2 \mathrm{~mm} \mathrm{Al}$ \\
Dycal & $1.49(0.03)^{\mathrm{b}}$ & $2 \mathrm{~mm} \mathrm{Al}$ \\
Hydro C & $1.47(0.02)^{\mathrm{b}}$ & $2 \mathrm{~mm} \mathrm{Al}$ \\
Enamel & $1.56(0.02)$ & $2 \mathrm{~mm} \mathrm{Al}$ \\
Dentin & $1.77(0.03)$ & $1 \mathrm{~mm} \mathrm{Al}$ \\
\hline
\end{tabular}

* Values with the same superscript letters are not significantly different at $p<0.05$. used as base must also follow the same criteria applied to posterior composed resins for radiopacity, in order to enable caries adjacent to the restorations and the dental structures to be differentiated ${ }^{3}$.

Analyzing the mean optical densities of the tested cements, only Life showed a statistically significant difference from the others. However, when the densities were expressed in equivalent aluminium thickness, all cements presented mean densities in the range equivalent to 2-mm aluminium. This can also be observed for the enamel that presented a mean optical density of 1.56. Therefore, all the tested materials, as well as the enamel, presented a radiopacity equivalent to 2-mm aluminium.

The results obtained in this study are in accordance with the specifications of the International Standards Organization, since $1 \mathrm{~mm}$ of the tested materials has a radiopacity equivalent to a greater thickness of aluminium ( $2 \mathrm{~mm})$, and thus these cements may be considered to be radiopaque. The significant difference found between the optical densities for Life cement (less radiopacity) probably does not have a clinical meaning for radiographic interpretation. Therefore it may be concluded that all tested cements presented radiopacity values similar to that of enamel.

Abreu, et al. ${ }^{2}$ classified Dycal in the group of cements presenting moderate radiopacity, meaning that it was not easily detectable in dental structures. However, McComb ${ }^{12}$ found the same radiopacity value as Life and Dycal and this value was greater than that of human dentin. These latter results agree with those found in this study.

The methodology applied to this study is similar to that used in most studies about the radiopacity of dental materials. Expression of radiopacity in the equivalent aluminium thickness allows comparison between the radiopacity of the tested materials and that of the surrounding dental structures (enamel and dentin). Moreover, it allows comparison between the results found in several studies, with some limitations due to the pureness of the aluminium used in the stepwedge ${ }^{22}$ and the different radiopacity values found for the enamel and dentin ${ }^{9}$.

The radiopacity value obtained for the enamel and dentin in this study is very similar to that found by Williams and Billington $^{23}$, who observed a radiopacity value of $2.1 \mathrm{~mm} \mathrm{Al}$ for enamel and $1 \mathrm{~mm} \mathrm{Al}$ for dentin. These data are also in agreement with van Dijken, et al. ${ }^{21}$, who showed that the radiopacity value of dentin is approximately equivalent to that of aluminium of the same thickness and that enamel is approximately two times more radiopaque than aluminium.

Thus, it was concluded that only Life showed a statistically significant difference in relation to the other two cements, presenting the lowest radiopacity. When using $\mathrm{mm}$ aluminium to express the radiopacity, all the tested cements presented a thickness equivalent to $2 \mathrm{~mm}$ aluminium, similar to that of enamel. 


\section{REFERENCES}

1- Abou-Tabl ZM, Tidy DC, Combe EC. Radiopacity of composite restorative materials. Br Dent J 1979;147:187-8.

2- Abreu MJN, Tavares D, Vieira DF. Radiopacity of restorative materials. Oper Dent 1977;2:3-16.

3- Akerboom HBM, Kreulen CM, van Amerongen WE, Mol A. Radiopacity of posterior composite resins, composite resin luting cements, and glass ionomer lining cements. J Prosthet Dent 1993;70:351-5.

4- Chan DCN, Titus HW, Chung KH, Dixon H, Wellinghoff ST, Rawls HR. Radiopacity of tantalum oxide nanoparticle filled resins. Dent Mater 1999;15:219-22.

5- Council on Dental Materials, Instruments, and Equipment. The desirability of using radiopaque plastics in dentistry: a status report. J Am Dent Assoc 1981;102:347-50.

6- El-Mowafy OM, Benmergui C. Radiopacity of resin-based inlay luting cements. Oper Dent 1994;19:11-5.

7- Espelid I, Tveit AB, Erickson RL, Keck SC, Glasspoole EA. Radiopacity of restorations and detection of secondary caries. Dent Mater 1991;7:114-7.

8- Goshima T. The radiopacity of composite restorative materials. Dentomaxillofac Radiol 1986;15:37-40.

9- Hara AT, Serra MC, Haiter-Neto F, Rodrigues ALJ. Radiopacity of esthetic restorative materials compared with human tooth structure. Am J Dent 2001;14:383-6.

10- International Standard Organization. ISO 4049: Dentistry polymer-based filling, restorative and luting materials. Switzerland: ISO; 2000.

11- Matsumura H, Sueyoshi M, Tanaka T, Atsuta M. Radiopacity of dentalcements. Am J Dent 1993;6:43-5.

12- McComb D. Comparison of physical properties of commercial calcium hydroxide lining cements. J Am Dent Assoc 1983;107:6101 .

13- Phillips RW. Skinner - materiais dentários. 9. ed. Rio de Janeiro: Guanabara-Koogan; 1993. p.268-74.

14- Prévost AP, Forest D, Tanguay R, DeGrandmont P. Radiopacity of glass ionomer dental materials. Oral Surg Oral Med Oral Pathol 1990;70:231-5.

15- Rubo MHM, El-Mowafy O. Radiopacity of dual-cured and chemical-cured resin-based cements. Int J Prosthod 1998;11:70-4.

16- Sewerin IB. Radiographic identification of simulated carious lesions in relation to fillings with Adaptic Radiopaque. Scand J Dent Res 1980;88:377-81.

17- Shah PMM, Sidhu SK, Chong BS, Pitt Ford TR. Radiopacity of resin-modified glass ionomer liners and bases. J Prosthet Dent 1997;77:239-42.

18- Sidhu SK, Shah PMM, Chong BS, Pitt Ford TRP. Radiopacity of resin-modified glass-ionomer restorative cements. Quintessence Int 1996; 27:639-43.

19- Skartveit L, Halse A. Radiopacity of glass ionomer materials. J Oral Rehabil 1996;23:1-4.

20- Tamburus JR. Radiopacidade de resinas compostas. Rev Odontol Univ São Paulo 1990;4:103-7.
21- van Dijken JWV, Wing KR, Ruyter E. An evaluation of the radiopacity of composite restorative materials used in class I and class II cavities. Acta Odontol Scand 1989;47:401-7.

22- Watts DC. Characterization of aluminium radiopacity standards for restorative materials. J Dent 1987;15:175-7.

23- Williams JA, Billington RW. A new technique for measuring the radiopacity of natural substance and restorative materials. J Oral Rehabil 1987;14:267-9. 